\title{
In Defense of Charity and Philanthropy
}

\author{
JOSEPH S. FULDA
}

\section{VIRTUE AND EFFICIENT PROVISION}

Shall charity be regarded as an inefficient deployment of monies for present consumption that could be better deployed by investing in the production of future wealth? Shall misers be regarded as greater benefactors of society than philanthropists? Some recent literature seems to argue so. For example, most of what Donald J. Boudreaux ${ }^{1}$ wrote in a recent column on philanthropy is both good economics and sound common sense. ${ }^{2}$ Likewise, there is much to admire in Candace Allen and Dwight R. Lee's ${ }^{3}$ intellectually provocative defense of misers. ${ }^{4}$ This having been said, what appears to be the core teaching of the former and the thesis of the latter are troubling to those who see capitalism as not simply the most efficient system for the delivery of quality goods and services to the masses but as the most moral system for the distribution of wealth in a manner harmonious with nature, nature's God, and human nature.

This thinking is troubling not just because of the specific arguments made by Boudreaux, Allen, and Lee, which we will take up shortly, but because it invites still further arguments urging the reduction of virtue to efficient provision. Consider: "The most successful entrepreneurs best satisfy the needs and wants of others as those others see them. Those who satisfy others most are the most virtuous. Therefore, the most successful entrepreneurs are the most virtuous men." None of our authors would assent to this crude reasoning, but, especially since it has some truth to it, some libertarians-perhaps followers of Ayn Rand-might say to such an

Joseph S. Fulda is Contributing Editor of The Freeman, Associate Editor of Sexuality \& Culture, and Columnist for Computers and Society. 
argument, "Just so." The principled liberal will reply, "Not so fast. Both premises are true, perhaps, but the conclusion does not follow. For although the most successful entrepreneurs best satisfy the needs and wants of others as those others see them, those others may be misguided in their priorities-and while the liberal society will never interfere with an individual's ends, misguided or not, no liberal need label every self-directed goal as best for the person who aspires to it, much less as morally best. Furthermore, as Adam Smith's most famous line reminds us, the successful entrepreneur need not act out of an impulse towards virtue and usually does not, while in the Western tradition, at least, intent (but not necessarily motive) is part of what defines virtue and vice."

\section{COMMON GROUND}

Before taking issue with Boudreaux, Allen, and Lee, let me state where I find common ground, and there is much of it, of course, for all of us share a common tradition. First, Boudreaux is of course right that judgments about individuals' generosity ${ }^{5}$ have no place in public discussion. Although he wrote of Bill Gates, the same is true of the latest casualty of the gossips, Al Gore. Second, Boudreaux' statement "Because profits represent only a small portion of entrepreneurs' net additions to society's wealth-and because no business can profit in the market without contributing at least as much to society as it earns in profits-market advocates note that there is nothing to give back. Profits obtained in the market are earned, never taken" (Boudreaux, 1) is unimpeachable and neatly encapsulates the argument against those who say corporations must "give back to the community where they made their fortunes."

Third, Boudreaux' characterization of many nonprofit organizations, "especially those . . . seeking greater government intervention" as "produc[ing] either no or negative returns" and that "[t]he ostensible beneficiaries of such giving . . . are seldom the direct objects of the alms-giver's intentions" (Boudreaux, 2) is all too true, as are Allen and Lee's further observations that a "drawback of giving money to nonprofit . . organizations is that much of it goes into appeals for more contributions rather than into promoting the organizations' stated objectives" and "as a percentage of revenues, private firms spend much less on advertising to attract customers 
than nonprofit ... organizations spend to attract donors, who typically have little motivation to monitor how their contributions are spent" (Allen and Lee, 216). It is also therefore true that "because the benefits of . . . philanthropists are associated with the intentions of identifiable donors, much [we would say "some"] of the value of those benefits is dissipated as people compete for their favor." (Allen and Lee, 216)

\section{THE ARGUMENTS}

Let us first summarize the arguments we find troubling in the words of their authors, substituting general terms for proper names as appropriate. ${ }^{6}$

Donald J. Boudreaux. "[M] any market supporters," Boudreaux avers, "assert that the greater an entrepreneur's charitable giving, the more admirable is that entrepreneur" (Boudreaux, 1). Yet, says Boudreaux, "[I]f [the successful entrepreneur] gave away a larger portion of his wealth to charities he would likely reduce the welfare of others rather than increase it" (Boudreaux, 1). These advocates of charity, Boudreaux continues, "mistakenly assume that [the successful entrepreneur] consumes his entire fortune" (Boudreaux, 1) when, in fact, "the vast bulk of [the successful entrepreneur's] fortune is in [company] stock" (Boudreaux, 2) and therefore if the successful entrepreneur "were stricken with an acute spasm of generosity and gave away a large bundle of his fortune" he "would likely harm society" (Boudreaux, 2). Since "[s]uccessful entrepreneurs have already created great wealth and opportunity for others" (Boudreaux, 2), they need not feel additional obligation. "If," however, "capitalists want to aid charities by reducing their own present consumption, that's grand" (Boudreaux, 2).

In summary, I believe Boudreaux' core teaching is best summed up by the eminent economist and social thinker, Thomas Sowell, who opined in a recent column, in a remarkably similar vein: "Any philanthropist who is in doubt as to the best place to put his money to help others should invest in the private economy, where it will serve purposes determined by the consuming public, rather than by coteries of self-righteous and self-important people spending other people's money."7 
Candace Allen and Dwight R. Lee. Allen and Lee's argument is their answer to the following hypothetical question lifted from their article:

Consider the following example of a rich miser, $\mathrm{M}$, and an equally rich philanthropist, P. Both were extremely and equally productive at creating wealth over their entrepreneurial careers. At age 50, they both retire, each with accumulated wealth of $\$ 10$ billion. The similarity between $\mathrm{M}$ and $\mathrm{P}$ ends when we consider how they enjoy their wealth during retirement. Mr. M spends almost nothing, getting his greatest pleasure from keeping his money in a secret vault buried beneath his modest house. He has no friends, wife, or offspring with whom to share his enormous wealth. ...

Mr. $\mathrm{P}$ is a jovial and generous man who spends lavishly on himself and his friends. He hosts extravagant parties in his mansions located in some of the most exotic parts of the world. ... But even his entertainment budget cannot come close to exhausting his wealth in his lifetime, so $\mathrm{P}$ also gives away hundreds of millions of dollars to worthy nonprofit organizations such as universities, art museums, symphony orchestras, and operatic companies, creating enjoyment and employment for still more people.

Each man dies on his 85th birthday, Mr. M with his money forever locked in his hidden vault, and Mr. P having just spent his last dollar. ... The question we ask is, which one of the two did more to benefit others? (Allen and Lee, 214)

The answer: "It is easy to establish that Mr. M did more to benefit others than did Mr. P." (Allen and Lee, 214) Why? Because "[b]y reducing the general price level a little, [the miser's] hoarding allowed others to buy a little bit more with their money, with the increase in their total purchases equal to what Mr. M could have spent himself. The only difference between Mr. M and Mr. P is that M allowed others to decide where employment opportunities should be expanded with their purchasing choices. So while there is no reason to favor Mr. M or Mr. P for creating employment, Mr. M's hoarding is really more generous than Mr. P's spending because the beneficiaries of hoarding can get what they want instead of what someone else wants for them." (Allen and Lee, 215) This is, I believe, the crux of their argument, although there are embellishments dealing with the failings of nonprofit organizations, failings that we concede. 


\section{IN REPLY: \\ THE ROLE OF CHARITY AND PHILANTHROPY IN THE FREE SOCIETY}

Both arguments present impeccable economic analyses, but neither has moral compass or takes full account of the facts. To begin with, we live in an age of government, an age where government sets the terms for debate, even when we don't realize it, and Boudreaux, Allen, and Lee refer to charity and philanthropy as if such activities were mostly carried out by nonprofit organizations as determined by the IRS. One can agree, as I do, that most nonprofit organizations are not charitable-in quoting from Allen and Lee, I twice used the ellipsis between "nonprofit" and "organizations" to remove the dubious qualifier "charitable"-yet still affirm the ubiquitousness and wholesomeness of charity. For charity not only begins at home; most charity is within the family or among friends. The parents who support their disabled child rather than institutionalizing him, the parents and spouses who pay for their loved ones' higher education, the parent who forgoes a career-and material betterment-to raise a child, the family who adopts a child in need of a home: These are the principal acts of charity in America, and they occur every day all over the land, quietly and heroically, and without any 26 USC 501(c)(3) organization's involvement. All of this is true charity; none of it is tax-deductible; none of it is measured and calculated by government statisticians and bureaucrats; all of this charitable activity is part of what makes America a good country of virtuous people.

Second, there is also some-more than a little-bona fide charity that is mediated by nonprofit organizations-and it is unfortunate that Boudreaux, Allen, and Lee use that special libertarian tone normally reserved for government in speaking about non-profits. Nonprofit organizations are private, not public, and are an often efficient form of voluntary organization: Just ask members of buyers' coöperatives and credit unions and listen. They also have a competitive advantage over profit-making concerns to compensate somewhat for the competitive disadvantage arising from the absence of the profit motive as guidance-namely, they pay no taxes. No doubt that is why buyers' coöperatives and credit unions offer lower prices and higher rates to their members, respectively. Money I invest in a productive enterprise may spread well-being but will be taxed twice or more; money donated to a nonprofit 
organization may go partly to increased overhead but not, at least, to the State!

Third, Boudreaux' core teaching must be that taking money out of the wealth-producing industries and marking it for consumption is harmful to society. It cannot be that his position is just that malconsumption by misguided nonprofits is harmful because he concludes his essay by remarking that he has no problem with giving to charities by reducing one's consumption, rather than one's investment in the creation of wealth. (I presume, of course, that he would limit this comment to charities properly so-called.)

What can we say to this? We can say, I think, that it is true, that society as a whole is "harmed" in the sense he intends "harm," yet that it misses the point. The purpose of charity in the free society is the redistribution of wealth from the better-off to the less-well-off, through volitive, private means. This will entail taking some money out of productive uses for consumption and it will entail a lower gross product, less wealth, and less wealth per capita, the "harm." But it will also mean greater wealth where it is most needed at the expense of lesser wealth where it is not as needed. ${ }^{8}$ The key consideration is volition: As long as the redistribution, however sterile - or even negative-from a strictly economic point of view, is volitive, it is morally and socially beneficial to both the donors and the recipients-and never mind per capita product. After all, the people helped by charity properly so-called can ill afford to wait for greater returns on production. The choice for the donor is often food for the poor now or twice as much a decade hence-when it will be too late. ${ }^{9}$ The efficient accumulation of capital serving to make the same physical effort count for more and more is at the heart of the free society. So are good men who will divert some of that capital accumulation for immediate and pressing needs of the less-well-off now.

Fourth, Allen and Lee go considerably further than Boudreaux and also go further than Walter Block ${ }^{10}$ who in his noted book's section on misers-which includes "savers" and "hoarders"-may have originated the defense of hoarders that Allen and Lee cite and expand upon. Block observed that those who hoard money take it out of circulation, thus lowering the general price level as fewer dollars chase the existing amount of goods and services. Thus the hoarder-Allen and Lee's miser-saves all holders of money a little bit, as they can now purchase more with their money. ${ }^{11}$ So much is 
surely sound economics. However, Block is careful in his introduction to make the following disavowal of his defense: "It does not presume to indicate how mankind may best live. It does not set out the boundaries between the good and the bad, between the moral and the immoral, between propriety and impropriety. . . . The defense . . . is thus a very limited one. . . It decidedly does not mean that these . . . are moral, proper, or good." ${ }^{12}$

Allen and Lee's thesis is considerably more radical for they argue with considerable wit that misers benefit society more than do philanthropists. It is not enough for them to simply defend misers as doing economic good; they are raised to the status of do-gooders in the best sense of the word! This Block does not say, and it is this position with which we take issue. ${ }^{13}$

We have already made the case for charity, but philanthropy is another matter. Since the truly rich usually engage in philanthropy as well as charity, we should explain here our understanding of the role of philanthropy in the free society. The philanthropist loves all his fellow men, not just the less-well-off; he acts to ennoble the masses and the elite, too, in those pursuits they undertake in work and for pleasure. He seeks the betterment of all mankind according to his beliefs. If he believes reading in libraries is a superior pursuit to television, midnight basketball to crime, opera to movies, museums to popular culture, doctoral study in philosophy or religion to study for a professional degree in psychology, he will subsidize these activities. In doing so, he recognizes that the masses do not share his views and that the market therefore prices these activities as very nearly unaffordable. He wishes, in his love for his fellow man, to change them for the better through the only means available in the free society, volitive means. Of course, he can seek to persuade them, but neither verbal persuasion nor persuasion-byexample, the two modes of change-seeking in others normally respected as libertarian, is genuinely effective. What is effective is putting one's funds where one's beliefs are and lowering the prices of the goods and services the philanthropist most believes in. ${ }^{14}$ With the prices thus lowered, the demand for them will rise.

Unlike charity, philanthropy is almost always accomplished through the mediation of nonprofit organizations, ${ }^{15}$ and, unlike charity, it is rarely personal, but is rather normally accomplished through the impersonal forces of the market-prices. This understanding of philanthropy is at odds with much libertarian thought, 
because it presupposes that the masses do not choose what is necessarily best for them, let alone what is best morally-while in no way negating their freedom to choose their own ends as natural right and as the best regime available. It also denies that seeking change in others, even massive, wholesale change, is wrongheaded, misguided, or futile. It just maintains that rather than using verbal persuasion or persuasion-by-example which don't work well, in any case, and which are often, quite frankly, obnoxious exercises in self-righteousness, a man who would seek massive, wholesale change in others should do so through market mechanisms, not directed at anyone in particular, but at mankind in general, by using funds acquired by satisfying the demands of the market to alter the market for favored goods and services. (It is interesting to note that this opportunity is available, under normal circumstances, only to those who have first shown themselves able to satisfy existing market needs.)

In summary, we are arguing that society has need-morally and spiritually - of many things for which there is not a market (or not a strong market) and that philanthropists provide those things of their own wealth to the betterment of all. We are arguing, in short, that, in a free society, moral and spiritual leadership can be provided by thoughtful philanthropists, as opposed to bureaucrats and politicians of every stripe.

The miser, in contrast, seeks nothing, and his benefits are passive. Moreover, his benefits are granted to all holders of money in proportion to their holdings: The rich gain most from the miser's withholding, not the poor, not the masses, not everyone. It is not just that the benefits of the miser are unseen and unintended, it is also that they are undirected; they merely reinforce what people will do anyway, making it a bit easier for them to accomplish their ends. We should, indeed, be grateful for this, but unlike directed charity or philanthropy, this is aimless giving, akin to a rich man riding in his limousine through the street and throwing money out his window as passersby snatch it up eagerly. Sure, they should be grateful (and probably are, too), but it is no wonder that such a man commands no respect akin to that of the charitable man or the philanthropist. Perhaps the miser, not being a self-promoter, deserves somewhat more gratitude than the rich man who gives aimlessly, throwing his money about with reckless abandon, but not much more. However superficially opposite the miser appears 
when compared to this sort of spendthrift, they are two of a kind. Both have abdicated responsibility for the virtuous stewardship of their fortunes. ${ }^{16}$

\section{NOTES}

1. Dr. Boudreaux is President of the Foundation for Economic Education, a classical liberal think-tank, and publisher of The Freeman.

2. Donald J. Boudreaux, "Bill Gates, Philanthropist," Notes from FEE (January 1998): 1-2 in The Freeman 48, Center.

3. Allen and Lee both teach economics; Lee, in fact, holds an endowed chair and, in addition, was, at the time he coauthored the article, a Contributing Editor of The Freeman, as is the present author.

4. Candace Allen and Dwight R. Lee, "In Defense of Markets and Misers," The Freeman 48 (April 1998), 213-216.

5 This is of particular importance when the discussion contains sufficient elements of falsehood to place the person being discussed "in a false light," a tortious invasion of privacy. This variety of wrongdoing is in addition to defamation and may apply even when the object of discussion is an object of praise. False or exaggerated praise causes much harm: It raises expectations that the object of praise cannot meet-and who then may suffer unwarranted, intense scrutiny followed by unwarranted, hostile condemnation; it may suggest that the object of praise is really the subject of praise, in tacit or not-so-tacit accord with the praise, thus calling into question his integrity and humility; and, more generally, it misrepresents what the person is about to his often severe detriment.

6. Thus, because Boudreaux writes "Gates is just one example. Everything said about him here applies to all successful entrepreneurs" (Boudreaux, 1), we will substitute "the successful entrepreneur" for "Bill Gates" or "Gates": We do this because we are interested not in Boudreaux" thesis that Mr. Gates ought not suffer reproach for apparent lack of charitable or philanthropic activity - we agree-but in his core teaching, in what his analysis of Gates' situation has to say in principle. Likewise, we will use "company" in place of "Microsoft" because we are interested in generalities and that particular example may obscure rather than illuminate the general case.

7. Thomas Sowell, "Thoughts on the Passing Scene," New York Post, September 4, 1998, p. 41. 
8. In these debates, free-market economists tend sometimes to forget the declining marginal utility of money marked for consumption!

9. This recalls a really fine philosophical article: Cliff Landesman, "When to Terminate a Charitable Trust?" Analysis 55 (January 1995), 12-13, in which the following dilemma is pointed out. One has a charitable trust which grows at a rate faster than human suffering. Thus, to maximize the amount of good the trust will do, it is necessary to keep postponing its termination. But, then, it will do no good at all! As both the author concedes and several replies in Analysis subsequently argued, there are ways to determine when to terminate the trust and disburse it to the poor even though it can never do maximal good.

10. Dr. Block's book (see n. 11, infra) is considered a libertarian classic. $\mathrm{He}$ is Professor and Chairman, Department of Economics and Finance, University of Central Arkansas.

11. Walter Block, "The Miser," Defending the Undefendable (San Francisco: Fox \& Wilkes, 1991 [1976]), pp. 105-109, esp. pp. 106-109.

12. Walter Block, op. cit., "Introduction," p. 12.

13. The astute reader may recall that Block has another section, "The Non-Contributor to Charity," pp. 120-126, in his book and that that section, although arguing from an entirely different perspective, goes much further than any of our authors would. In the opinion of the present writer, the subsection entitled "The Evils of Charity" is damnable and we very much doubt that the author still adheres to it.

14. It follows that we take issue with Allen and Lee's note 4 (Allen and Lee, 216) suggesting that latitude in how the beneficiary of philanthropy spends the funds is desirable. As we argued long ago, [Joseph S. Fulda, "The New Bondage," The Freeman 32 (April 1982), 243-248.] that is, indeed, true of charity: Help those less-well-off without dictating to them how to live. But with philanthropy, such latitude destroys its raison d'être and no one should make a philanthropic donation unless he is certain that the money donated will directly lower the price of the good or service thought ennobling by the full amount donated or will be used-since money is fungible-for projects and programs that he is certain would not otherwise be funded at all.

15. However, it is also often the case that a for-profit entity may receive the philanthropist's largesse, if, in his opinion, the good or service it offers for sale is thought ennobling. In this case, although there is a market for the company's product, that market can be expanded by a reduction in price.

16. Given this result, what then does Block's observation show? I think what he has shown is something else entirely, the impossibility of destroying 
money. This presents a problem for those who have come into possession (or even title) of tainted money. If the possessor cannot-either by operation of law or by circumstance-find a way to determine to whom the money rightfully belongs and to return it, and the law properly understood and applied does not allow him to acquire the money, he is out of options. Block has shown that doing nothing is not an option, and that "destroying" the money is not an option. Likewise making a charitable or philanthropic gift out of money which is not one's to give makes a mockery out of those noble enterprises. I am unaware of a solution to this problem and invite reader comment, directed to fulda@acm.org with subject "Tainted Money," on this matter. 